\title{
Nigeria's 1969 Curriculum Conference: a practical approach to educational emancipation
}

\author{
Conferência Curricular Nigéria 1969: \\ uma abordagem prática para a emancipação educativa \\ Conferencia Curricular Nigeria 1969: \\ un enfoque práctico para la emancipación educativa.
}

Grace Oluremilekun AKanbi ${ }^{1}$ OLURemi Adenike Abiolu ${ }^{2}$

\begin{abstract}
After Nigeria got her independence on 1 October, 1960, the general consensus was that there was the need for educational emancipation through decolonization of the academic contents of education; to make education relevant to the needs of the individual and the society at large. This led to the organisation of the 1969 Curriculum Conference which had far-reaching effects on the curriculum contents, purposes, goals and objectives of education in Nigeria. However, what obtains in the education sector today makes it to look as if there was no initial proper planning for educational emancipation. This paper, therefore, focuses Nigeria's 1969 Curriculum Conference (CC) as a practical approach to educational emancipation in Nigeria. In the conceptual framework of the globalisation of education, Cookey's (1972: xxv) observation during the conference that, "education then tends to produce children who can read and write and pass examinations and which qualify them for employment only as clerks" was an important reason for the conference and is still relevant today as a major issue for discussion in our education outcomes. This study is historical; it, therefore, employs the historical method to collect information and facts needed through both primary and secondary sources. As the study recommends among others that there is the need for total overhauling of Nigerian educational policies and philosophy, it is hoped that the research would sensitise all stakeholders in Nigeria to emphasise the importance of providing a functional educational curricula relevant to the needs of individuals and the society at large.
\end{abstract}

Keywords: Curriculum Conference, Emancipation, National Policy on Education, Decolonisation.

\footnotetext{
${ }^{1}$ Department of Educational Foundations, School of Education, Emmanuel Alayande College of Education, Oyo Town, Oyo State, Nigeria. Email: ayo4remi@gmail.com; oluremiakanbi2004@yahoo.co.uk

2 The Federal University of Technology, Akure, Nigeria. E-mail: ijatuyioa@yahoo.com
} 


\section{Resumo}

Após a Nigéria conseguir sua independência em 1 de outubro, 1960, o consenso geral era que havia a necessidade da emancipação educative por meio da descolonização dos conteúdos acadêmicos de educação; para tornar a educação relevante às necessidades do indivíduo e da sociedade em geral. Isso levou à organização da Conferência Curricular de 1969 que teve efeitos extensos nos conteúdos curriculares, propósitos, metas e objetivos de educação na Nigéria. No entanto, o que se obtêm no setor de educação hoje faz parecer que não havia planejamento inicial adequado para emancipação educacional. Este artigo, portanto, foca na Conferência Curricular de 1969 da Nigéria (CC) como uma abordagem prática para a emancipação educativa na Nigéria. Na estrutura conceitual da globalização da educação, a observação de Cookey (1972: xxv) durante a conferencia que, "educação então tende a produzir crianças que podem ler e escrever e passar exames e que as qualificam para emprego apenas como escriturários" foi uma importante razão para a conferência e ainda é relevante hoje em dia como uma questão principal de discussão nos resultados da nossa educação. Este é um estudo histórico; ele, portanto, emprega o método histórico de coleta de informações e fatos necessários tanto por fontes primárias quanto secundárias. Como o estudo recomenda inclusive que há uma necessidade por total revisão das políticas e filosofia educacionais da Nigéria, é esperado que a pesquisa possa sensibilizar todas as partes interessadas na Nigéria em enfatizar a importância de prover um currículo de educação funcional relevante às necessidades dos indivíduos e da sociedade em geral.

Palavras-chave: Conferência curricular, Emancipação, Política Nacional de Educação, Descolonização.

\section{Resumen}

Después de que Nigeria obtuvo su independencia el 1 de octubre de 1960, el consenso general consistía en que era necesaria la emancipación educativa a través de la descolonización de los contenidos académicos de la educación, hacer que la educación fuera relevante para las necesidades del individuo y de la sociedad en general. Esto condujo a la organización de la Conferencia Curricular de 1969, que tuvo efectos de gran alcance en los contenidos, propósitos, metas y objetivos de la educación en Nigeria. Sin embargo, lo que se obtiene hoy en el sector de la educación hace que considere que no hubo una planificación inicial adecuada para la emancipación educativa. Este documento, por lo tanto, se enfoca en la Conferencia Curricular de 1969 (CC) de Nigeria como un enfoque práctico para la emancipación educativa en Nigeria. En el marco conceptual de la globalización de la educación, la observación de Cookey (1972: xxv) durante la conferencia refiriéndose a que "la educación tiende a producir niños que pueden leer y escribir y aprobar exámenes y calificándolos para el empleo solo como empleados", era un motivo importante de la conferencia, continuando relevante hoy como un importante tema para el debate en nuestros resultados educativos. Este es un estudio histórico; por lo tanto, emplea el método histórico para recopilar información y hechos necesarios a través de fuentes primarias y secundarias. Como el estudio recomienda, entre otros, la necesidad de una revisión total de las políticas y la filosofía educativas nigerianas, se espera que la investigación sensibilice a todas las partes interesadas en Nigeria para enfatizar la importancia de proporcionar un currículo educativo funcional relevante para las necesidades de las personas y la sociedad en general.

Palabras clave: Conferencia Curricular. Emancipación. Política Nacional de Educación. Descolonización. 


\section{Introduction}

The independence granted to Nigeria by the colonial masters on October 1, 1960, gingered her to the necessity of embarking on the processes of educational emancipation through total decolonisation of the academic contents, principles and practices of education. The 1969 curriculum conference, therefore, was an important practical step taken then by Nigeria towards the emancipation of its educational system. The conference was a culmination of expressions of general disaffection with the existing educational system which had become irrelevant to national needs, aspirations and goals (Federal Republic of Nigeria, 2011: 14). Therefore, it was summoned mainly "to review old and identify new national goals for education in Nigeria at all levels (primary, secondary, tertiary) and provide guidelines on what the system should be accomplishing with respect to the needs of youths and adults individuals in our society" (Adaralegbe, 1972: xiii). The peculiarity of this conference was the caliber of people that participated: Academic institutions at all levels, local governments, various ministries, trade unions, publishing houses among others. They were drawn from all segments of the society to ensure an emergence of a concrete educational policy. The effect of the curriculum conference on the educational development in Nigeria has been monumental. It led to the evolution of the first indigenous policy on education (National Policy on Education; NPE) that was first published in 1977, and subsequently reviewed in 1981, 1988, 2004 and 2013. The policy charted a direction for education in Nigeria by stating what the philosophy and goals of education should be in an independent Nigeria, while a system of education, 6-3-3-4, conceived to be relevant and functional was also adopted. That is why the importance of the 1969 curriculum conference cannot be overemphasised.

\section{Problem of this Study}

The fact that the 1969 curriculum conference was timely and very relevant at the time it was organised cannot be overemphasised. It was well thought out, planned and executed. A comprehensive report - a philosophy for Nigerian education - was even presented to the federal government as the outcome of the conference. This report eventually led to the adoption of 6-3-3-4 system of education. However, the whole scenario in the education sector looks as if there was no initial proper planning for educational emancipation in Nigeria. Where did things go wrong and what is responsible? Why is the education system in Nigeria still in chaos almost fifty years after the conference that was supposed to chart a course for educational advancement of the nation? These and other issues that may be incidental to this few questions will be addressed in this study as it focuses discussion on:

- the historical background to educational development in Nigeria;

- the role of education in the curriculum emancipation process;

- why the curriculum conference was organised;

- the focus of discussion during the conference;

- the effects of the conference on the educational development of Nigeria; and,

- where the direction of education should be in Nigeria now. 


\section{Sources of Information for this Paper}

This is a historical study; it, therefore, employs the historical method to collect information and facts needed through both primary and secondary sources. Relevant textbooks and journals have been consulted to source for relevant information, however, it is very important to put it succinctly that the major source of information has been the report of the 1969 curriculum conference titled "A Philosophy for Nigerian Education" edited by Adeniji Adaralegbe and published in 1972. This has to be so because of the importance of the conference as a major practical step in the educational emancipation of Nigeria. Also, the report is comprehensive and revealed in a plain and unprejudiced manner all that transpired during the conference including the participants that cut across all facets of professions and leanings. Apart from these facts, the outcome of the conference led to the publication of the first NPE in 1977 and has continued to be reviewed. In other words, the conference has led to an indigenous policy of education in Nigeria.

\section{The Historical Background of Educational Development in Nigeria}

On 24 September 1842, a team of Missionaries from the Wesleyan Methodist Missionary Society (WMMS), led by Sir Thomas Birch Freeman, which also included Mr. and Mrs De Graft came to Badagry and established the first school named "Nursery of the Infant Church" (Fafunwa 1974: 79, Taiwo 1980). The WMMS team was closely followed by the Church Missionary Society (C.M.S.) in December 1842, which moved to Abeokuta in 1846 and established two schools, one for boys and the other for girls under the supervision of Samuel Ajayi Crowther and his wife. In December 1858, the first school in Onitsha for girls between 6 and 10 years old was also opened by Crowther. In 1847, the United Free Church of Scotland started work in Calabar; in 1887 the Qua Iboe Mission started work in the Eket and Uyo districts, also the Primitive Methodists in Calabar and Owerri Provinces in 1894 (Otonti, 1965; Fafunwa, 1974). Converting Africans to Christianity via education was the main focus of the Missionaries; this is why the establishment of missions was always followed by the opening of primary schools. As Taiwo (1980) observed, the earliest schools were without any doubt an adjunct of the church, and education was purely a Missionary affair.

While the Christian missions with their evangelistic and educational activities were going on in the coastal and southern parts of Nigeria, Islam with its Arabic influence according to Ukeje and Aisiku (1982) was already firmly established in the northern part. This is why when Western education became the prevalent and dominant type of education in the south; Qur'anic education remained, for many decades, the only kind of formal education in the North. Eventually, when the Christian missions began to penetrate into the north, their activities were restricted to the non-Muslim areas which accounted in part, for the educational gap between the South and the North in Nigeria up till today. Prior to 1882, when the first education ordinance was promulgated, which applied to all British West Africa, the colonial government paid little attention to education and was merely interested in using the products of the mission schools as clerks, messengers and interpreters. Subsequently, and before independence, educational administration was by ordinances; and which included the 1882, 1887, 1916, 1926, 1948 and 1952 Educational Ordinances and Regional Laws of 1954 (Labo-Popoola, Bello \& Atanda 
2009), yet curricula and other elements were largely determined by each denomination to suit its needs, and no mission focused science and technology education. The principles and practice of education within this period was therefore not satisfactory.

The Richard's Constitution of 1946 and subsequent Macpherson Constitution of 1951 which was revised in 1954 - divided Nigeria into three regions (Eastern, Western and Northern) and empowered each region to have its own educational autonomy respectively. The promulgation of the 1952 Education Ordinance then empowered each of the regions to develop its educational policies and systems (Taiwo, 1980; Fafunwa, 2004) and the Colonial Education Board was abolished. The outcome was the promulgation of the Education Law No. 6 of 1955 in the Western Region, the Education Laws No. 28 of 1956 in the Eastern Region and Education Law No. 17 of 1956 in Northern Region and the Lagos Education Act, No. 26 of 1957 (Taiwo, 1980). With these regional laws, education and other social services become the centre point of the government in each of the regions up till the time of independence. After independence, there was a civil war between 1967 and 1970 that disrupted and slowed down the pace of educational development that was started by the regions.

\section{The Role of Education in the Curriculum Emancipation Process}

The role of education in any form of development cannot be overemphasised. Real education broadens the horizon of educated fellows opening their eyes to view issues from different perspectives thus leading to more education and effective contributions to all facets of life in the society. This is in consonance with Dewey's (2012: 57) submission that:

Since in reality there is nothing to which growth is relative save more growth, there is nothing to which education is subordinate save more education. It is a common place to say that education should not cease when one leaves school. The point of this commonplace is that the purpose of school education is to insure the continuance of education by organizing the powers that insure growth.

Also, Fafunwa (1974: 156) observed that "one definite contribution made by education has been the political enlightenment of the people, particularly the educated elite" The exposure to Western education no doubt, helped Nigerians and brought about awareness of their rights and privileges under the various constitutions and the Universal Declaration of Human Rights. Also, exposure of the nationalists and politicians to education opportunities and programmes outside the country increased the tempo of agitations for emancipation.

The formation of the National Council of Nigeria and the Cameroons (N.C.N.C.) by the Nigerian students in 1944, which later became a political party led by Herbert Macaulay and Dr. Nnamdi Azikwe, the Action Group (AG) in 1951 by Chief Obafemi Awolowo and the Northern People's Congress (NPC) in 1952 by Sir Ahmadu Bello, all happened because of their awareness through education. The N.C.N.C., in particular, was a collection of prominent individuals, such as teachers, clerks, professional people, and groups such as labour unions, ethnic organisations etc., with its main goal to win self-government for Nigeria as soon as possible (Taiwo, 1980). Awareness and the consciousness of the evils of colonialism, and the 
awareness of the enormity of human and material resources available in Nigeria stirred up the struggles by Nigerians to control their own destiny which eventually led to the attainment of independence on October 1, 1960. After independence, the 1969 curriculum conference that was organised, was part of the emancipation process and the eventual evolution of the NPE in 1977, this was possible because people were educated and knew what they wanted.

\section{Why the Curriculum Conference was organised}

In the report of the Presidential Task Team on Education (PTTE) (FRN, 2011: 14), the 1969 curriculum conference was "Nigeria's move to join the African education train, and particularly to evolve a genuinely national education system". The 1969 curriculum conference "was the forum for the discussion of a wide range of issues and problems underlying the determination of an appropriate curriculum for the nation's schools" (Adaralegbe, 1972). The conference became necessary, according to Adaralegbe, because there has been a constant outcry by educators, parents, government functionaries, the laymen, scholars, and the press of the ills of Nigerian educational system, and particularly the inadequacy of the school curriculum to develop individual Nigerians and the nation at the rate and tempo to put her on the world map. Also, the Nigeria Educational Research Development Council (NERDC) thought it was worthwhile to search for a national philosophy of education hence, the conference was summoned to review old and identify new national goals for education in Nigeria at all levels (primary, secondary, tertiary) and provide guidelines on what the system should be accomplishing with respect to:

\section{The needs of youths and adult individuals in our society.}

2. The socio-economic needs, values, aspirations and development of our society.

3. The curriculum substance, the subject content of the system which is the means to the goals. (Adaralegbe, 1972: xiii).

The organisation of the conference was also necessitated by what was observed by Sampson (1972: 237) that before the conference:

The educational systems in Nigeria were chaotic . . . each state in the federation (twelve states then) has its own separate educational system, a total of twelve systems. In primary education, some States are operating the eight-year course while others are running the six-year course. In secondary education, there are such varied systems as secondary modern, secondary grammar, secondary technical and secondary commercial schools. . . Not surprisingly, the different educational systems in the country also result in a lack of uniformity in educational standards. . .

In the submissions of Adaralegbe (1972), the conference scope was inevitably limited by the available time, the kind of issues raised, the feasibility of the resolutions, and the desire to get the ideal learning situation for Nigerian children. However, the structure of the conference was given by three major tasks: 
1. Identification and clarification of a national philosophy, goals, purposes and objectives.

2. Statement of issues and problems.

3. Development of implications and recommendations for a national curriculum reform.

\section{The Focus of Discussion during the Conference}

Discussions during the conference focused two main items - purposes of education, and, implications for implementation. These were broken into seven plenary sessions as follow:

\section{A. Purposes of Education}

1. The purpose of primary education.

2. The purpose of secondary education.

3. The purpose of university education.

\section{B. Implications for implementation}

4. Teacher's education.

5. Education of women.

6. Education for living.

7. The role of science and technology in national development.

As summarised in the report, the conference discussed among others the following problems and issues:

1. Who controls, manages, and finances the schools?

2. Who decides what to teach and how?

3. How can the school curriculum be designed to develop the individual potentialities of all members of our nation within the framework of our unity in diversity?

4. What are the distinctive responsibilities of the school in contrast to those of the family, the church, industry, and the other various educative agencies (youth organisations, the radio, and the press)?

5. What is the school role in dealing with national problems specifically in the areas of national unity, national development, national reconstruction, social and economic well- being, and personal development of the citizenry?

6. How can the school deal with controversial issues within the context of the concepts of personal development and the fundamental freedom of the individual?

7. Should the schools consciously gear their programmes towards the present and future occupational opportunities of students, or the national manpower development or both or neither?

8. What constitutes a balanced curriculum programme for the individual in his social, political and economic context amidst various pressures for specialisations? (Adaralegbe,1972: xv-xvi) 


\section{The Effects of the Conference on the Educational Development of Nigeria}

In the opinion of Adaralegbe (1972: xiv), "bringing together of diverse shades of opinion by people from different walks of life to discuss the education of the Nigerian child is the most significant of the achievements of the conference". Another important fact is that "for the first time, it has been possible for Nigerians to deliberate, by themselves, on the aims and goals of education suited for their children". The acknowledgement by foreign observers of the level of the discussion and major decision in the conference was "an eloquent affirmation of faith in the democratic participatory process in curriculum development".

To the researchers, however, an overwhelming outcome of this conference is the evolution of NPE and the 6-3-3-4 system of education, though in 2008 was reformed to 9-3-4 system of education. The implication is that a blueprint for Nigeria's education is now available. After the conference, and before the evolution of the NPE, according to Obioma (2013), there were follow-up activities which included wide national consultations, a seminar of experts from educational ministries, establishments, voluntary agencies and international organisations; all, to evolve a policy that will attract wide acceptability by all and sundry. The policy focus, according to the PTTE; (FRN, 2011: 14) "was a radical modification of the inherited colonial education system, which was considered elitist and too literary-oriented". Functional education through enhancing curriculum relevance to reflect national cultural heritage, and inculcating needed skills for development in various sectors, with particular emphasis on science and technology was, therefore, the main intention of the policy. It should be noted that if the outcome of the conference had been adequately implemented, Nigeria would have joined the league of developed nations with sound and functional education with less focus on acquisition of certificates.

\section{What went wrong and what is responsible?}

At this juncture, it is necessary to beam searchlight on some questions. Where did things go wrong and what is responsible? Why is the education system in Nigeria still in chaos, to the extent that some people are even calling for a declaration of state of emergency in the sector; almost fifty years after the conference that was supposed to chart a course for educational advancement of the nation?

One important perennial issue to note is that formulation of excellent policies in Nigeria has never been a problem, but oftentimes, they are bedeviled by poor implementation or lack of adequate preparation for the take-off. According to Akanbi (2017a), "for any policy to be successful, there must be some inbuilt mechanisms that make room for the processes of implementation, monitoring, supervision, feedback, evaluation, improvement, reorientation, effectiveness, and the like". This submission, then, makes Akindoyeni's (2014) observation also relevant to this discourse. He believes that for any policy to be effective it must focus a definitive need, provide a legal framework for the implementation with definite implementation strategies, its interpretation must not be ambiguous, make provision for effective monitoring and evaluation leading to periodic review, among others; some of which was lacking in the NPE. 
In the opinion of the PTTE, one of the things that went wrong was that the 6-3-3-4 was being operated as a skeletal structure whereas, it requires 'flesh and blood' in terms of addressing more fundamental education issues contained in the policy such as:

a. Language of instruction in the early years of schooling;

b. Learner-centered pedagogy

c. Student Guidance and Counselling;

d. Systematic Learning Assessment;

e. Teaching for mastery;

f. Diversification of Curricula;

g. Minimum Qualification Level for Teachers;

h. Modification of Structure of Tertiary Education;

i. Integrating the Non-formal Component of Education;

j. Religious, Ethical and Moral Values in Education;

k. Systematic Monitoring of the System (FRN, 2011: 16-17)

Without addressing effectively and urgently the issues above and with all sincerity of purpose, 'the children will pass through the school without the school also passing through them'; implying they would not be functional despite the fact that they have been certified.

Inadequate funding and the mismanagement of the little allocated to the education sector is almost becoming monumental. Since 1960 and up till 2015, budgetary allocation to education has not met the UNESCO recommendation of at least $26 \%$ of any nation's budget. The highest budgetary allocation to education in Nigeria in this twenty-first century has been $10.4 \%$ in 2006 (Akanbi, 2017b). Unfortunately, the allocations are spent not invested; this is because much of it is used up by recurrent expenditure.

Another thing that went wrong was that vocational subjects are treated as pure sciences in content, arrangement and methodology; even agriculture (Olaitan, 1994); and this is a colonial legacy. Whereas, through effective teaching of vocational subjects, unprecedented innovations and technological breakthroughs could be achieved as students' latent skills are brought to the fore.

According to Akanbi (2014), whatever name we decide to call our policy; 6-3-3-4 or 6-94 , almost there everything that is required is lacking in most school environment, especially in government public schools, to effectively implement the policy structure. Maintenance culture is excessively bad and it seems nobody is bothered. Nossiter (2012) also observed that some students, both in the primary and secondary schools, are taught in the open air under trees. According to the report of Vision 2020 National Working Group on Education Sector (2009), the learning conditions in schools are alarming: Paucity of teaching materials (few textbooks, in many schools no charts or teaching aids, children in many cases having only their exercise books for taking notes), absence of adequate furniture, over-crowded classrooms, lack of ventilation, and general dilapidated condition of many of the school buildings. 


\section{What the Direction of Education should be in Nigeria now: Recommendations}

Functional education is a must if Nigeria will achieve total emancipation. Quoting Zeilberger (1961), Obanya (2004:27) brought out "the key principles of Functional Education as; developing the intellectual and non-intellectual abilities of the child, rather than 'forcefeeding' the child with facts that are readily forgotten because they are "like foreign substances without any connection to the child's life". This may be the reason why during the curriculum conference, the wider sense of the meaning of education "as the training of the entire person to enable him not only to be able to read and write and calculate or to be proficient in a given job, but also to enable him to fit himself for living in the society" (Cookey, 1972: xxii) was adopted for the purpose of discussion. This was also what informed the adoption of the 6-3-3-4 system at the conference.

Innocent-Ene (2008), quoting Ivowi (1997), agreed with the latter's summation of the essential ingredients of school education as:

1. Basic literacy for functional living in the society;

2. Basic concepts and principles as a preparation for further studies;

3. Essential skills and attitudes as preparation for application of subject matter for development; and

4. Stimulation and enhancement of creativity.

Also, from Obanya's (2004) perspective, "there is a radical paradigm shift from narrow specializations to more broad based knowledge and from specific to generic skills. These generic skills make adaptation to the changing demands of the workplace possible; they make continuous on-the-job easier" The generic skills are:

1. Analytical power: an advanced capacity for logical reasoning.

2. Communication: oral and written.

3. Problem solving: the ability to task and maximize one's analytical power in proffering solution to variety of problems.

4. Team spirit: being able to make meaningful contributions to variety of group activities, and relating to others while remaining oneself.

5. Creativity: going beyond well-known thinking and action paths.

6. Versatility; exhibiting a broadened horizon in the domain of knowledge and competence.

7. Lifelong learning skills:

8. Information Technology: both as discipline on its own and tool to support other disciplines and life activities. (Obanya (2004: 17).

That is why by now, in the opinion of Innocent-Ene (2008), for everybody to fight poverty, the education system should be functional; such that every course of study should provide an alternative to government work. It has also become important that entrepreneurship training takes a centre-stage in Nigerian education because of the increase in the prevalence of unemployment. Also, to redress the current economic situation in Nigeria, 
urgent action has to be taken through proper implementation of the technical and vocational education and training TVET policy (Akanbi, 2017a). It doesn't speak well that at this age of Nigeria's independence, we still rely heavily on importation of goods and services including food. Agricultural and technological education should take premium place in our curriculum in practical terms.

"Since no education system may rise above the quality of its teachers" (FRN, 2004: 33), teachers should be given the proper attention that they deserve; good remuneration and enabling teaching environment. The direction of education now should be towards including skill acquisition in the curriculum of teacher education to encourage the teachers to impart it in their learners. Education now should emphasise leading by example. Until teachers are able to demonstrate multi-task skills, students may not believe that it is possible.

\section{Conclusion}

The 1969 Curriculum conference no doubt was a practical step at the educational emancipation of Nigeria after the independence. It was borne out of genuine intention to have an education that is relevant to the needs and aspirations of the nation and its citizens. The conference was also determined to fashion out functional education that would equip the citizens with skills that would make the economy of the nation solid enough to compete with developed nations. However, the intentions have been marred by poor implementation of the outcome of the conference - the NPE. There has been no enabling teaching and learning environment and, lack of renewal of the curricula contents to accommodate global developments in areas of science and technology. This is imperative in line with Dewey's (2012: 12) opinion that "it is the very nature of life to strive to continue in being. Since the continuance can be secured only by constant renewals, life is a self-renewing process. What nutrition and reproduction are to physiological life, education is to social life". To this end, revision of educational policies, in theory, will no longer suffice; rather such reviews should be accomplished by practical evaluation and review of the implementation of the policies.

\section{References}

Adaralegbe, A. (ed., 1972). A philosophy for Nigerian education. Ibadan, Nigeria: Heinemann Educational Books (Nigeria) Ltd.

Akanbi, G. O. (2016). Charting Future Directions for Education in Nigeria: The Need for Good Politics and Political Will. In M. Omolewa (Ed.) Discourse on the State of Education in Nigeria. A Book of Readings in Honour of Professor Israel Olu Osokoya. Ibadan: Laurel Educational Publishers. (pp. 549-568).

Akanbi, G. O. (2017a). Changing bodies, degenerating output: phases of Basic Education in Nigeria from 1914 to 2014. Education History Notebooks, 16(1) 180-195. http://dx.doi.org/10.14393/che-v16n1-2017-12 
Akanbi, G. O. (2017b). Prospects for technical and vocational education and training (TVET) in Nigeria: Bridging the gap between policy document and implementation. The International Education Journal: Comparative Perspectives 16(2) 1-15. https://openjournals.library.sydney. edu.au/index.php/IEJ

Akindoyeni, A. (2014). The Nigerian Policy Implementation performance: perspective and challenge. Part I. In The Guardian, Friday, June 13, page 68

Cookey, S. J. (1972). The need to review the purpose of education in present day Nigeria In A. Adaralegbe (ed.). A philosophy for Nigerian education (pp. xxi-xxxiv). Ibadan, Nigeria: Heinemann Educational Books (Nigeria) Ltd.

Dewey, J. (2012). Democracy and education. USA: Simon \& Brown

Fafunwa, A. B. (1974). History of Education in Nigeria. London: George Allen and Unwin.

Federal Ministry of Education (2007). Nigeria education sector diagnosis: a platform for reengineering the education sector. Abuja: Nigeria Education Sector Analysis (ESA) Unit.

Federal Republic of Nigeria (1977). National Policy on Education. Lagos: NERDC

Federal Republic of Nigeria (1988). National Policy on Education. Lagos: NERDC

Federal Republic of Nigeria (2004). National Policy on Education (4th Edition) Lagos: NERDC

Federal Republic of Nigeria (2011). Main Report of the Presidential Task Team on Education. Abuja: Federal Ministry of education.

Federal Republic of Nigeria (2013). National Policy on Education and 4-year strategic plan for the development of the education sector (6th Edition) Lagos: NERDC

Labo-Popoola, S. O.; Bello, A. A. \& Atanda, F. A. (2009) Universal Basic Education in Nigeria: Challenges and Way Forward. Pakistan Journal of Social Sciences 6 (5) 252 - 259.

Nossiter, A (2012). Wielding fire: Islamists target Nigerian schools. Accessed on June 8, 2014 at http://www.nytimes.com/2012/03/26/world/Africa/in-nigeria-boko-haramtargetsschools.html?

Obanya, P. A. I. (2004). Educating for the Knowledge Economy. Ibadan, Nigeria: Mosuro Publishers.

Otonti, N. (1965). Western Education and the Nigerian Cultural Background. Ibadan: University Press Limited.

Sampson, E. (1972). New Education for new Nigeria (pp.236-241). In, A. Adaralegbe (Ed.). A Philosophy for Nigerian Education. Ibadan: Heinemann Educational Books (Nigeria) LTD.

Taiwo, C.O. (1980). The Nigerian Educational System: Past, Present, and Future. Lagos: Thomas Nelson (Nigeria) Limited.

Ukeje, O. and Aisiku, J. U. (1982). Education in Nigeria In A. B. Fafunwa and J. U. Aisiku (Eds.). Education in Africa: A comparative survey (205-234). London: George Allen \& Unwin. 